\title{
SISTEM INFORMASI AKUNTASI ARUS KAS PADA KANTOR DESA BOBANEIGO KEC.KAO TELUK KABUPATEN HALMAHERA UTARA
}

\section{CASH FLOW ACCOUNTING INFORMATION SYSTEM AT THE BOBANEIGO VILLAGE OFFICE KAO SUB-DISTRICT, NORTH HALMAHERA REGENCY}

\author{
Muhdar Abdurahman ${ }^{1}$, Akil Thalib ${ }^{2}$, Arisandy Ambarita ${ }^{3}$ \\ ${ }^{1,2}$ Program Studi Manajemen Informatika, Akademi Ilmu Komputer (AIKOM) Ternate \\ ${ }^{3}$ Program Studi Manajemen Informatika \\ Politeknik Sains dan Teknologi Wiratama Maluku Utara \\ muhdarabdurahman@gmail.com
}

\begin{abstract}
Abstrak
Tujuan Penelitian ini adalah Merancang System Informasi Akuntansi Pelaporan arus kas pada Kantor Desa Bobaneigo Kec. Kao Teluk, mempunyai sasaran terhadap aparat desa agar dapat dengan mudah mengelola keuangan dengan baik sehingga efektif dalam penyajian informasi laoporan arus kas pada setiap bulanya. Adapun langkah-langkah penelitian ini adalah: Tahap Pendahuluan untuk mengidentifikasi permasalahan, yaitu proses pengumpulan data dan informasi. tinjauan pustaka proses pengumpulan data dan literature. Kemudian Tahap pembuatan perangkat lunak yaitu dengan Analisis kebutuhan system yang sedang berjalan dan proses system yang berjalan untuk kebutuhan user. Tahap berikutnya adalah Desain system. Implementasi dan Testing Sistem. Dengan adanya Sistem yang dibuat ini dapat mempermudah pegawai dalam pembuatan laporan pada kantor desa
\end{abstract}

Kata kunci: Sistem Informasi Akuntansi, Arus Kas, Kantor Desa

Abstract

The purpose of this study is the Accounting Information Designing System for cash flow reporting at the Bobaneigo Village Office Sub-district, North Halmahera Regency has a target of village officials so that they can easily manage finances well so that they are effective in presenting monthly cash flow reports, The steps of this research are: Preliminary Phase to identify problems, namely the process of collecting data and information, literature review process for collecting data and literature, Then the stage of making software is to analyze the needs of the running system and the running system processes for user needs. The next step is system design. System Implementation and Testing. With this system created can facilitate employees in making reports at the village office

Keywords: Accounting Information System, Cash Flow, Village Office

\section{PENDAHULUAN}

Dana Desa (satu miliar) per desa merupakan program pemerintah saat ini. Membangun Indonesia memulai dari desa, infrastruktur sampai pada ekonomi desa. Tentunya kesiapan desa terutama (SDM)
Suber Daya Manusia menjadi hal utama pada penegelolaan system aparatur desa, khususnya bidang pengelolaan keuangan. Ini menjadi pokok permasalahan sehingga disimpulkan bahwa penyediaan Sistem informasi akuntansi terarah pada arus kas. 
Karena kas dalam neraca merupakan aset yang paling likuid, hampir setiap transaksi yang dilakukan oleh fungsi yang berwenang atau yang terkait secara kelembagaan maupun dengan pihak lain yang sebagian besar akan mempengaruhi kas.

Perancangan System Informasi Akuntansi Pelaporan arus kas, mempunyai sasaran terhadap aparat desa agar dapat dengan mudah mengelola keuangan dengan baik sehingga efektif dalam penyajian informasi laoporan arus kas pada setiap bulanya Desentralisasi kewenangan-kewenangan yang lebih besar disertai dengan pembiayaan dan bantuan sarana prasarana yang memadai mutlak diperlukan guna penguatan otonomi desa menuju kemandirian desa. Pengelolaan keuangan desa merupakan bagian penting yang menjadi tolok ukur peningkatan dan kemajuan kualiatas aparat desa dalam menjalankan tugas pelayanan baik secara administrasi maupun tindakan pelayanan soaial terhadap masyarakat pada umumnya. Prosedur Pengelolaan system keuangan desa, menjadi organ terpenting pada tata kelola pemerintahan desa, pengelolaan system keuangan terkadang tidak sesuai dengan prosedur mengakibatkan tatanan serta kebijakan aparat desa,tidak terarah dan terjadi ketimpangan sehingga berdampak pada masyarakat secara menyeluruh.Rangkaian permasalahan ini menjadi dasar pemikiran, bagaamana menyajikan sebuah system keuangan desa tentang laporan arus kas disetiap bulanya, dari system konvensional dikembangkan secara terkomputerisasi.

Pada arah dan tujuanya diharapkan pemerintah desa dapat menjalankan system pengelolaan keuangan, laporan arus kas disetiap bulanya, sebagai salah satu pengendalian keuangan internal pemerintah desa. Pada sisi lain kegunaan dan atau manfaat dapat memberikan kemudahan aparat desa disetiap pengambilan keputusan serta menyajikan pelaoran untuk melaporkan laporan pertanggung jawaban keuangan kepada masyarakat. Efektifitas dari tingkat pengelolan aparatur desa yang baik, khususnya pengelolaan keuangan dengan standar system serta prosedur, dapat berpotensi meningkatkan kinerja aparat desa sehingga berdampak positif terhadap lingkungan perintahan desa maupun masyarakat pada umumnya.

\section{Rumusan Masalah}

Bagaimana Merancang Sistem Infromasi Akuntansi Arus Kas Pada Kantor Desa Bobaneigo Kec. Kao Teluk Kabupaten Halmahera Utara

\section{LANDASAN TEORI}

\section{Pengertian Akuntansi}

Menurut Rudianto (2012:4) akuntansi adalah sistem informasi yang menghasilkan informasi keuangan kepada pihak-pihak yang berkepentingan mengenai aktivitas ekonomi dan kondisi suatu perusahaan

Menurut Reeve, Warren, dkk (2005), akuntansi adalah sistem informasi yang menghasilkan laporan kepada pihak-pihak yang berkepentingan mengenai aktivitas ekonomi dan kondisi perusahaan.

\section{Pengertian Sistem Informasi Akuntansi}

Menurut Azhar Susanto (2013:72) Sistem informasi akuntansi pada dasarnya merupakan integrasi dari berbagai sistem pengolahan transaksi. Berikut ini komponen (sistem pengolahan transaksi) sistem informasi akuntansi menurut Azhar Susanto (2013:72) diantaranya:

1. Hardware 
2. Software

3. Brainware

4. Prosedur

5. Database

6. Jaringan komunikasi.

\section{Pengertian Penerimaan Kas}

Menurut Soemarso (2009) penerimaan kas adalah suatu transaksi yang menimbulkan bertumbuhnya saldo kas dan bank milik perusahaan yang diakibatkan adanya penjualan hasil produksi, penerimaan piutang maupun hasil transaksi lainnya yang menyebabkan bertambahnya kas.

\section{Pengertian Pengeluaran Kas}

Menurut Soemarso S.R (2004; 299) Kas adalah segala sesuatu (baik yang berbentuk uang maupun bukan uang) yang dapat tersedia dengan segera dan diterima sebagai alat pelunasan kewajiban pada nominalnya.

\section{Pengertian laporan Keuangan}

Menurut Munawir Sjadzali (2004) pengertian laporan keuangan adalah proses akuntansi yang dapat digunakan sebagai alat untuk mengkomunikasikan data keuangan.

\section{Pengertian Sistem Informasi}

Menurut Jogiyanto (2013) sistem mempunyai karakterisktik atau sifat-sifat tertentu, yaitu mempunyai komponenkomponen (components), batasan sistem (boundary), lingkungan luar sistem (environments), penghubung (interface), masukan (input), keluaran (output), pengolah (process), dan sasaran (objectives) Informasi pada dasarnya adalah sehimpunan data yang telah diolah menjadi suatu yang memiliki arti dan kegunaan yang lebih luas. kualitas informasi (quality of information) harus dapat memenuhi beberapa yaitu : Akurat, Relevan dan Tepat Waktu. Akurat berarti informasi harus bebas dari kesalahan dan tidak bisa menyesatkan. Tepat Waktu, berarti Informasi yang datang pada penerima tidak boleh terlambat. Releven, berarti informasi tersebut mempunyai manfaat untuk pemakainya.

\section{Perancangan Sistem}

Kenneth dan Jane (2008) menjelaskan bahwa perancangan sistem adalah kegiatan merancang detil dan rincian dari sistem yang akan dibuat sehingga sistem tersebut sesuai dengan requirement yang sudah ditetapkan dalam tahap analisa sistem. Lebih lanjut O'Brien dan Marakas (2009:639) menjelaskan bahwa perancangan sistem adalah sebuah kegiatan merancang dan menentukan cara mengolah sistem informasi dari hasil analisa sistem sehingga dapat memenuhi kebutuhan dari pengguna termasuk diantaranya perancangan user interface, data dan aktivitas proses.

\section{Road Map Penelitian}

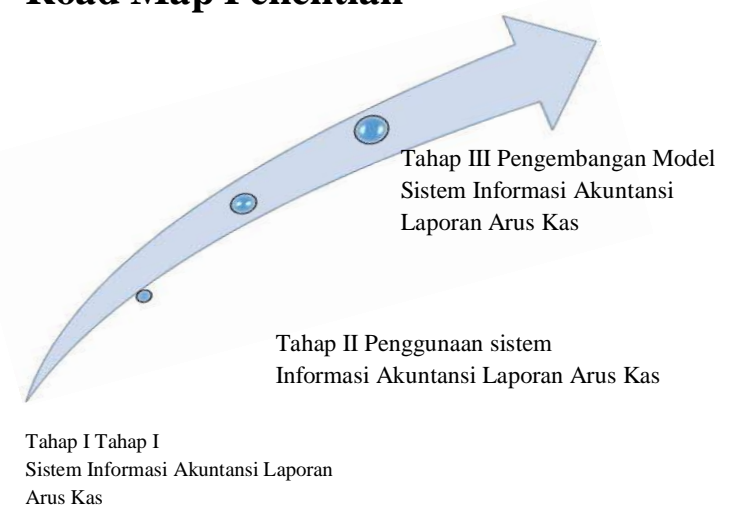

METODE PENELITIAN

Lokasi dan Waktu Penilitian

Lokasi penelitian dilakukan di Desa BobaneIgo Kec. Kao Teluk Halmahera 
Utara. Waktu penelitian selama Bulan Januari sampai dengan Bulan Agustus

\section{Teknik Pengumpulan Data}

Metode ini menggunakan Data primer, yaitu jenis data yang diperoleh secara langsung melalui wawancara, dokumen-dokumen, foto atau gambar fasilitas yang ada pada objek yang di tiliti. Menurut Sugiyono (2013:224) teknik pengumpulan data merupakan langkah yang paling strategis dalam penelitian, karena tujuan utama dari penelitian adalah mendapatkan data.Metode pegumpulan data yang digunakan.

\section{Metode Analisis dan Pengembangan Sistem}

Metode Analisis sistem yang digunakan dalam penelitian ini adalah model driven secara terstruktur dengan pendekatan bottom-up dimana pendekatan ini dimulai dari level bawah organisasi. Merumuskan keutuhan-kebutuhan untuk menangani transaksi yang dimulai datadata input, proses dna output admin dengan alat bantu Flowchart membuat kerangka konsep system

Metode pengembangan sistem yang digunakan adalah Waterfall Modelling dimana proses dilakukan secara berurutan. Dengan metode ini, diharapkan dapat menghasilkan sistem yang lebih baik karena memungkinkan adanya evaluasi kembali terhadap proses pengembangan sistem. Apabila sistem yang dikembangkan kurang sesuai dengan kebutuhan, maka pengembangan dapat ditinjau Kembali untuk dapat di analisis lanjut agar lebih sempurna, Berikut merupakan tahapan pengembangan system yang diuraikan sebagai berikut

\section{Alat dan Bahan yang digunakan}

Alat dan Bahan merupakan variabel terpenting dalam kegiatan penelitian ini karena untuk memaksimalkan pengembangan Sistem informasi Laporan Keuangan Arus Kas Kantor Desa Bobaneigo, berikut merupakan spesifikasi alat dan bahan yang digunakan dalam penelitian:

1. Hardware
a. Laptop Lenovo Thinkpad X25 Processor Intel Core i5
b. Ram 4 GB.
c. Hardisk 500 GB.
d. Printer Canon Pixma iP 2770.

2. Software.

e. Sistem operasi windows 7 ultimate

f. Microsoft Office visio 2016 untuk mendesain sistemMicrosoft Office 2007 untuk membuat hasil laporan

g. Bahasa Pemrograman HTML, CSS, MySQL

h. Xampp sebagai web server dan media database

\section{Kerangka Penilitian}

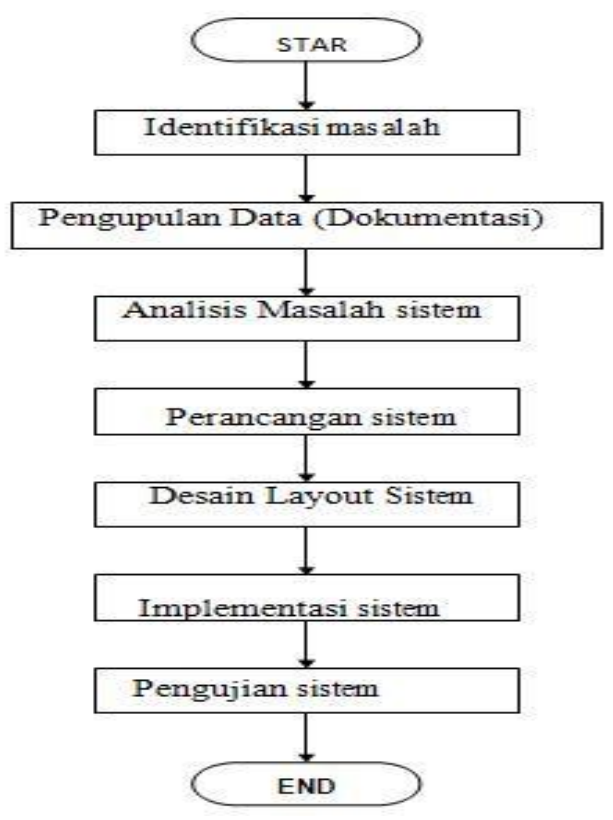

Gambar 1. Kerangka Penilitian

\section{Analisa Sistem yang Berjalan}

Analisa sistem yang berjalan 
merupakan tahapan dalam melakukan indentifikasi masalah awal pada sistem yang masih konvensional dan diuraikan pada diagram flowchart sistem yang berjalan

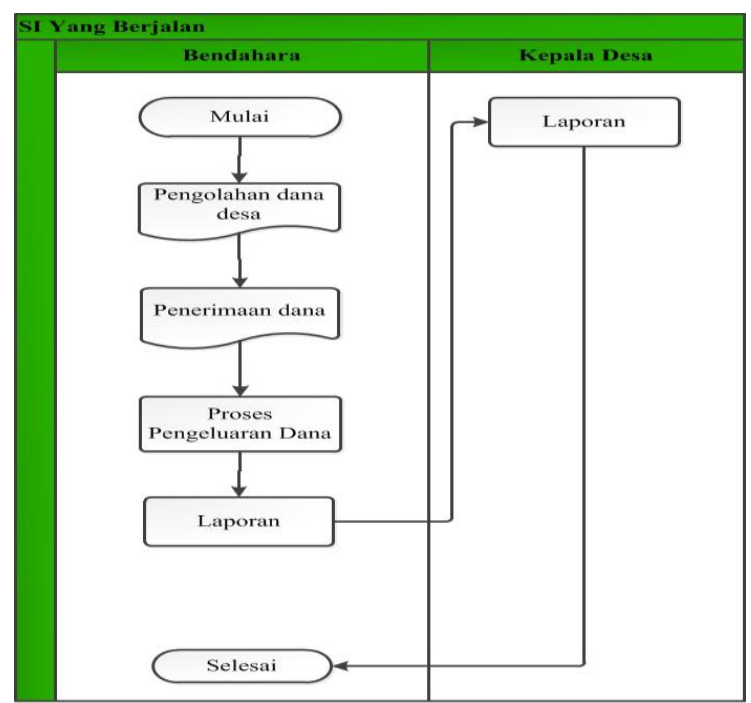

Gambar 2. Sistem yang berjalan

\section{Rancangan System yang Diusulkan}

Berdasarkan sistem yang berjalan maka peneliti mengusulkan sistem yang baru. Berikut desain flowchart sistem yang diusulkan.

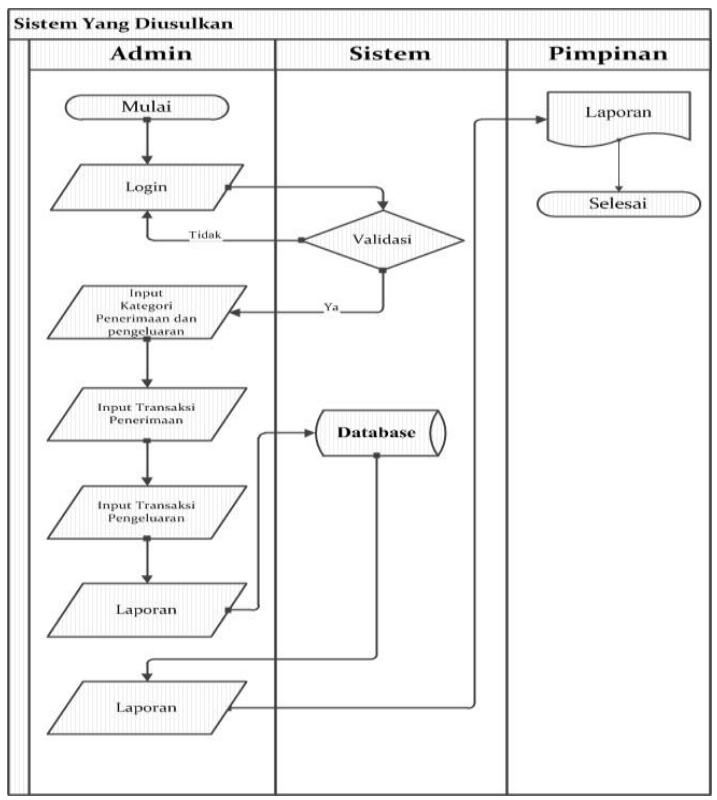

Gambar 3. Flowchart Sistem Yang Diusulkan

Kebutuhan Fungsional a. Admin Melakukan Login dan Logut pada Sistem

b. Admin Menginput, Mengedit dan Menghapus Data User, Data Kas, Data Transaksi

c. Admin mencetak Laporan Kas dan Rekapan transaksi

\section{Kebutuhan Non-Fungsional}

a. Sistem di jalankan pada system operasi windows 7 Ultimate 32 Bit

b. Sistem dapat dijalankan pada Google Chrome.

c. Sistem berjalan pada RAM 2 GB.

d. Menggunakan Bahasa Pemrograman HTML, CSS, PHP

\section{PERANCANGAN SISTEM}

\section{Perancangan Tabel Database}

Rancangan tabel merupakan rancangan database untuk menyimpan seluruh data - data yang di input pada sistem, berikut adalah uraian tabel pada Sistem Informasi Pelaporan Keuangan Desa Berbasis Web Pada Kantor Desa Bobaneigo Kecamatan Kao Teluk.

Tabel User

Tabel 1. User

\begin{tabular}{|l|l|l|l|}
\hline $\begin{array}{l}\text { Nama } \\
\text { Field }\end{array}$ & $\begin{array}{l}\text { Data } \\
\text { Type }\end{array}$ & size & Ketrangan \\
\hline id & Int & 11 & primary \\
\hline Usertype_id & int & 11 & \\
\hline name & varchar & 50 & \\
\hline nama & varchar & 50 & \\
\hline password & varchar & 32 & \\
\hline email & varchar & 50 & \\
\hline store & int & & \\
\hline type & varchar & 50 & \\
\hline
\end{tabular}

Tabel UserRoles

Tabel 2. UserRoles

\begin{tabular}{|l|l|l|l|}
\hline Nama Field & $\begin{array}{l}\text { Data } \\
\text { Type }\end{array}$ & size & Ketrangan \\
\hline id & int & 11 & primary \\
\hline
\end{tabular}




\begin{tabular}{|l|l|l|l|}
\hline User_id & int & 11 & \\
\hline Role_id & int & 11 & \\
\hline
\end{tabular}

\section{Tabel Out category}

Tabel 3. out category

\begin{tabular}{|l|l|l|l|}
\hline Nama Field & $\begin{array}{l}\text { Data } \\
\text { Type }\end{array}$ & size & Keterangan \\
\hline id & int & 11 & primary \\
\hline code & varchar & 100 & \\
\hline name & varchar & 50 & \\
\hline Entry_by & varchar & 50 & \\
\hline Entry_time & timestap & & \\
\hline
\end{tabular}

\section{Tabel Incategory}

Tabel 4. Incategory

\begin{tabular}{|l|l|l|l|}
\hline Nama Field & $\begin{array}{l}\text { Data } \\
\text { Type }\end{array}$ & size & Ketrangan \\
\hline id & int & 11 & primary \\
\hline code & varchar & 100 & \\
\hline nama & varchar & 50 & \\
\hline Entry_by & varchar & 50 & \\
\hline Entry_time & timestap & & \\
\hline
\end{tabular}

\section{Tabel Journal}

Tabel 5. Journal

\begin{tabular}{|l|l|l|l|}
\hline Nama Field & $\begin{array}{l}\text { Data } \\
\text { Type }\end{array}$ & size & Ketrangan \\
\hline id & int & 11 & primary \\
\hline tanggal & date & 11 & \\
\hline Incategory_id & int & 11 & \\
\hline Outcategory_id & int & & \\
\hline debet & double & & \\
\hline kredit & double & & \\
\hline keterangan & varchar & 200 & \\
\hline Entry_by & varchar & 100 & \\
\hline Entry_time & timestap & & \\
\hline
\end{tabular}

\section{Diagram Konteks}

Diagram konteks merupakan rancangan umum system yang nantinya akan dibangun oleh programmer, berikut rancangannya yang ditampilkan pada gambar berikut:

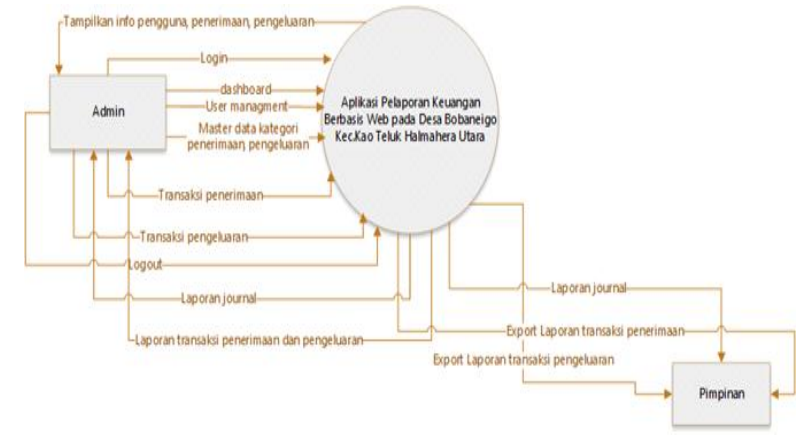

Gambar 9. Diagram Konteks

\section{DFD Level 0}

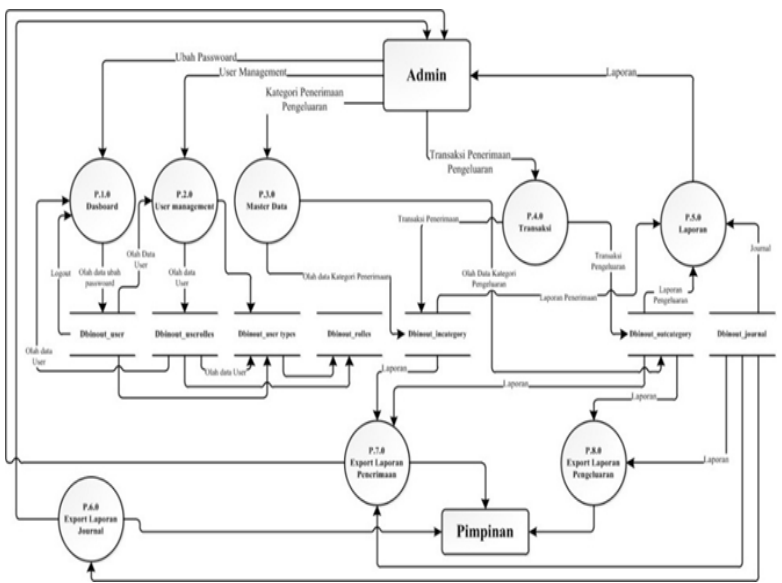

Gambar 10. Diagram Level 0

\section{ERD Relasi Tabel}

Entity Relationship Diagram atau yang biasa disingkat ERD merupakan rancangan model database relasi antar entity dan objek, berikut merupakan hasil rancagan ERD relasi tabel

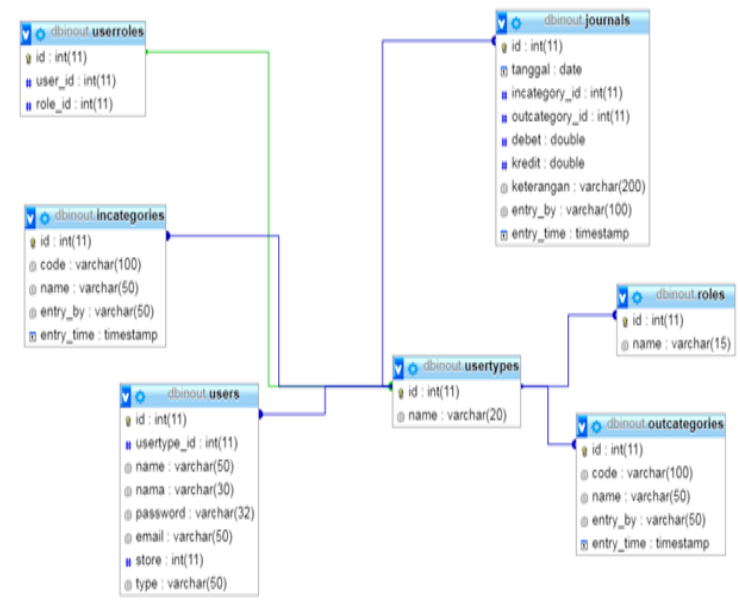

Gambar 11. Relasi Tabel 
Entity Relationship Diagram (ERD)

Notasi

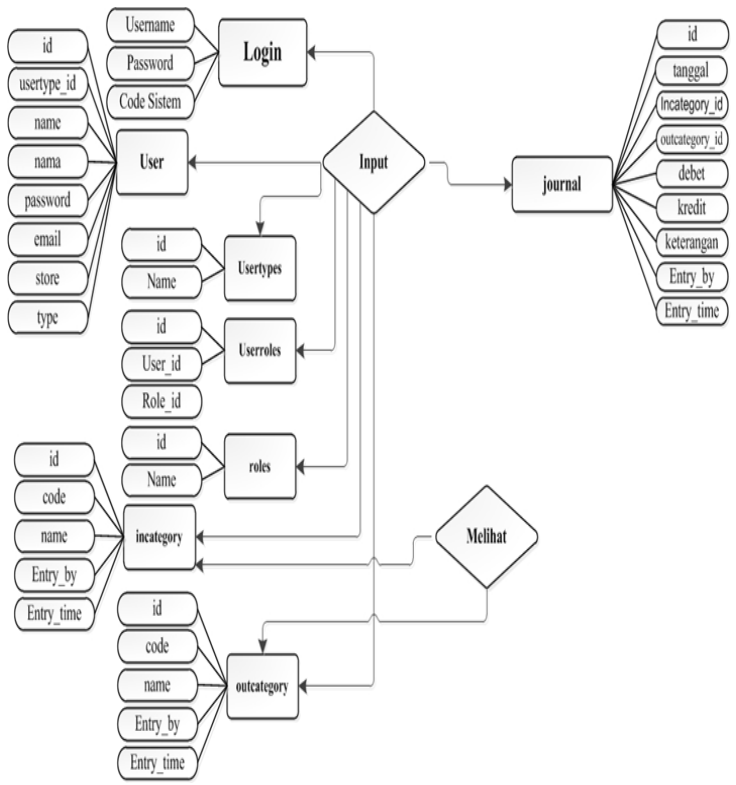

Gambar 12. Erd Notasi

\section{IMPLEMENTASI SISTEM}

Implementasi sistem merupakan tahapan meletakan sistem yang sudah dibuat ke dalam bahasa pemrograman dan nantinya sistem tersebut akan diuji

\section{Menu Utama}

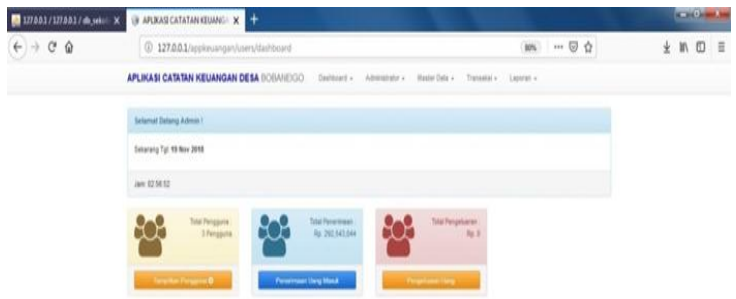

Gambar 13. Tampilan Menu utama Admin

\section{Halaman Menu Login}

APLIKASI CATATAN KEUANGAN DESA BOBANEIGO

\section{Login}

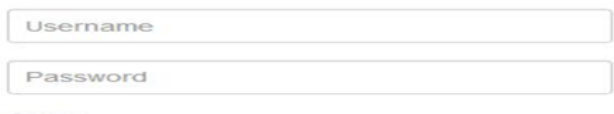

Code

$243 a 1$

insert code

Submit

Gambar 14. Menu Login Admin

\section{Halaman Menu Dashboard}

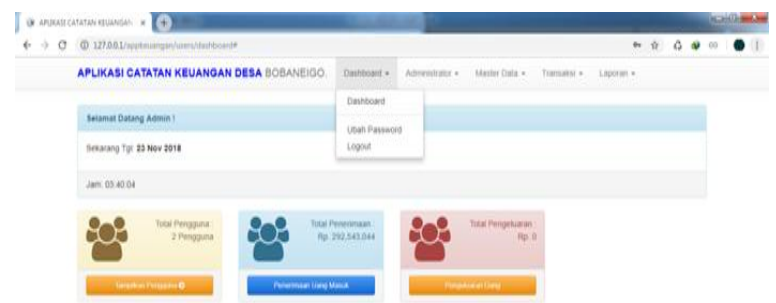

Gambar 15. Menu Dashboard

\section{Halaman Menu Administrator}
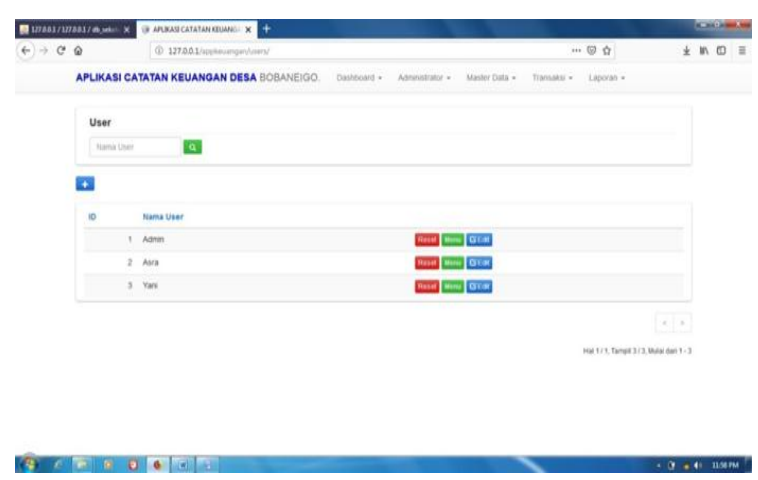

Gambar 16. Menu Administrator

\section{Halaman Menu Laporan}

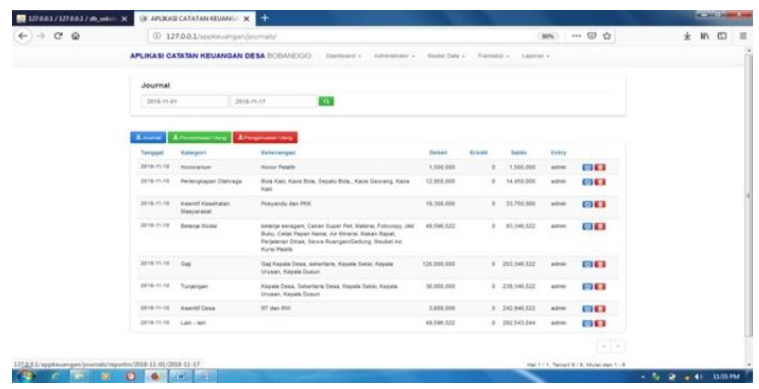

Gambar 12. Menu Laporan 
Pengujian Sistem Blackbox

\begin{tabular}{|c|c|c|c|c|}
\hline $\begin{array}{l}\mathbf{N} \\
\mathbf{0}\end{array}$ & $\begin{array}{c}\text { Tampila } \\
\text { n antar } \\
\text { muka }\end{array}$ & Uji Coba & $\begin{array}{c}\text { Keteran } \\
\text { gan }\end{array}$ & $\begin{array}{c}\text { Hasil } \\
\text { Pengujia } \\
\text { n }\end{array}$ \\
\hline \multirow[t]{2}{*}{1} & \multirow[t]{2}{*}{$\begin{array}{l}\text { Tampilan } \\
\text { Login } \\
\text { Admin }\end{array}$} & \multirow[t]{2}{*}{$\begin{array}{l}\text { Menguji } \\
\text { Proses } \\
\text { login }\end{array}$} & $\begin{array}{l}\text { Berhasil } \\
\text { Melakuk } \\
\text { an }\end{array}$ & \multirow{2}{*}{$\begin{array}{l}\text { Berhasil } \\
\text { Masuk } \\
\text { Ke Menu } \\
\text { Utama } \\
\text { admin }\end{array}$} \\
\hline & & & $\begin{array}{l}\text { Validasi } \\
\text { Gagal } \\
\text { Melakuk } \\
\text { an } \\
\text { Validasi }\end{array}$ & \\
\hline 2 & $\begin{array}{l}\text { Tampilan } \\
\text { Dasboard } \\
\text { Ubah } \\
\text { Password }\end{array}$ & $\begin{array}{l}\text { Menguji } \\
\text { Proses } \\
\text { Menu } \\
\text { Dasboard } \\
\text { Ubah } \\
\text { Password }\end{array}$ & $\begin{array}{l}\text { Berhasil } \\
\text { masuk ke } \\
\text { menu } \\
\text { yang } \\
\text { dipilih, } \\
\text { menginp } \\
\text { ut, } \\
\text { menyimp } \\
\text { an } \\
\text { Password } \\
\text { yang baru }\end{array}$ & $\begin{array}{l}\text { Berhasil } \\
\text { Merubah } \\
\text { password }\end{array}$ \\
\hline 3 & $\begin{array}{l}\text { Tampilan } \\
\text { Administ } \\
\text { rator } \\
\text { User } \\
\text { manage } \\
\text { ment }\end{array}$ & $\begin{array}{l}\text { Menguji } \\
\text { Proses } \\
\text { Menu } \\
\text { Administ } \\
\text { rator } \\
\text { User } \\
\text { Manage } \\
\text { ment }\end{array}$ & $\begin{array}{l}\text { Berhasil } \\
\text { masuk ke } \\
\text { menu } \\
\text { user } \\
\text { managem } \\
\text { ent dan } \\
\text { melakuka } \\
\mathrm{n} \\
\text { penamba } \\
\text { han, } \\
\text { penginpu } \\
\text { tan, } \\
\text { penyimpa } \\
\text { nan dan } \\
\text { pencarian } \\
\text { data }\end{array}$ & $\begin{array}{l}\text { Berhasil } \\
\text { menamb } \\
\text { ah, } \\
\text { menginp } \\
\text { ut, } \\
\text { mengedit } \\
\text { menyimp } \\
\text { an dan } \\
\text { mencari }\end{array}$ \\
\hline 4 & $\begin{array}{l}\text { Tampilan } \\
\text { Master } \\
\text { data } \\
\text { Kategori } \\
\text { Penerima } \\
\text { an }\end{array}$ & $\begin{array}{l}\text { Menguji } \\
\text { proses } \\
\text { menu } \\
\text { master } \\
\text { data } \\
\text { kategori } \\
\text { penerima } \\
\text { n }\end{array}$ & $\begin{array}{l}\text { Berhasil } \\
\text { masuk ke } \\
\text { menu } \\
\text { Katrgori } \\
\text { Penerima } \\
\text { an dan } \\
\text { melakuka } \\
\text { n } \\
\text { penamba } \\
\text { han, } \\
\text { penginpu } \\
\text { tan, } \\
\text { Penyimp } \\
\text { ana } \\
\text { pengedita } \\
\text { n, } \\
\text { pencarian }\end{array}$ & $\begin{array}{l}\text { Berhasil } \\
\text { melakuk } \\
\text { an } \\
\text { penamba } \\
\text { han, } \\
\text { penginpu } \\
\text { tan, } \\
\text { penyimp } \\
\text { anan, } \\
\text { pengedit } \\
\text { an, } \\
\text { pencaria } \\
\text { n dan } \\
\text { melihat } \\
\text { data }\end{array}$ \\
\hline 5 & $\begin{array}{l}\text { Tampilan } \\
\text { Menu } \\
\text { Master }\end{array}$ & $\begin{array}{l}\text { Menguji } \\
\text { proses } \\
\text { menu }\end{array}$ & $\begin{array}{l}\text { Berhasil } \\
\text { masuk ke } \\
\text { menu }\end{array}$ & $\begin{array}{l}\text { Berhasil } \\
\text { melakuk } \\
\text { an }\end{array}$ \\
\hline
\end{tabular}

\begin{tabular}{|c|c|c|c|c|}
\hline & $\begin{array}{l}\text { data } \\
\text { Kategori } \\
\text { Pengelua } \\
\text { ran }\end{array}$ & $\begin{array}{l}\text { master } \\
\text { data } \\
\text { kategori } \\
\text { penngelu } \\
\text { aran }\end{array}$ & $\begin{array}{l}\text { Katrgori } \\
\text { Penerima } \\
\text { an dan } \\
\text { melakuka } \\
\mathrm{n} \\
\text { penamba } \\
\text { han, } \\
\text { penginpu } \\
\text { tan, } \\
\text { Penyimp } \\
\text { ana } \\
\text { pengedita } \\
\text { n, } \\
\text { pencarian }\end{array}$ & $\begin{array}{l}\text { penamba } \\
\text { han, } \\
\text { penginpu } \\
\text { tan, } \\
\text { penyimp } \\
\text { anan, } \\
\text { pengedit } \\
\text { an, } \\
\text { pencaria } \\
\text { n dan } \\
\text { melihat } \\
\text { data }\end{array}$ \\
\hline 6 & $\begin{array}{l}\text { Tampilan } \\
\text { Menu } \\
\text { Transaks } \\
\text { i } \\
\text { Penerima } \\
\text { an }\end{array}$ & $\begin{array}{l}\text { Menguji } \\
\text { proses } \\
\text { menu } \\
\text { Transaks } \\
\text { i } \\
\text { Penerima } \\
\text { an }\end{array}$ & $\begin{array}{l}\text { Berhasil } \\
\text { masuk ke } \\
\text { menu } \\
\text { Transaksi } \\
\text { Penerima } \\
\text { an dan } \\
\text { melakuka } \\
\text { n } \\
\text { penginpu } \\
\text { tan, } \\
\text { Penyimp } \\
\text { ana. }\end{array}$ & $\begin{array}{l}\text { Berhasil } \\
\text { melakuk } \\
\text { an, } \\
\text { penginpu } \\
\text { tan, } \\
\text { penyimp } \\
\text { anan, } \\
\text { pengedit } \\
\text { an, } \\
\text { pencaria } \\
\text { n dan } \\
\text { melihat } \\
\text { data }\end{array}$ \\
\hline 7 & $\begin{array}{l}\text { Tampilan } \\
\text { Menu } \\
\text { Transaks } \\
\text { i } \\
\text { Pengelua } \\
\text { ran }\end{array}$ & $\begin{array}{l}\text { Menguji } \\
\text { proses } \\
\text { menu } \\
\text { Transaks } \\
\text { i } \\
\text { Penerima } \\
\text { an }\end{array}$ & $\begin{array}{l}\text { Berhasil } \\
\text { masuk ke } \\
\text { menu } \\
\text { Transaksi } \\
\text { Penerima } \\
\text { an dan } \\
\text { melakuka } \\
\text { n } \\
\text { penginpu } \\
\text { tan, } \\
\text { Penyimp } \\
\text { ana. }\end{array}$ & $\begin{array}{l}\text { Berhasil } \\
\text { melakuk } \\
\text { an, } \\
\text { penginpu } \\
\text { tan, } \\
\text { penyimp } \\
\text { anan, } \\
\text { pengedit } \\
\text { an, } \\
\text { pencaria } \\
\text { n dan } \\
\text { melihat } \\
\text { data }\end{array}$ \\
\hline 8 & $\begin{array}{l}\text { Tampilan } \\
\text { Menu } \\
\text { Laporan }\end{array}$ & $\begin{array}{l}\text { Menguji } \\
\text { proses } \\
\text { menu } \\
\text { Laporan }\end{array}$ & $\begin{array}{l}\text { Berhasil } \\
\text { masuk ke } \\
\text { menu } \\
\text { laporan } \\
\text { dan } \\
\text { melakuka } \\
\mathrm{n} \\
\text { pengeksp } \\
\text { oran, } \\
\text { pengedita } \\
\mathrm{n} \\
\text { Dan } \\
\text { penyyim } \\
\text { pan }\end{array}$ & $\begin{array}{l}\text { Berhasil } \\
\text { melakuk } \\
\text { an, } \\
\text { pengedit } \\
\text { an, } \\
\text { pencaria } \\
\text { n dan } \\
\text { pengeksp } \\
\text { oran } \\
\text { laporan }\end{array}$ \\
\hline
\end{tabular}

KESIMPULAN 
Dari hasil implementasi dan pengujian sistem, maka peneliti mengambil kesimpulan sebagai berikut:

1. Sistem yang dibuat ini mempermudah pegawai dalam pembuatan laporan pada kantor desa.

2. Sistem ini hanya membuat laporan keuangan secara efisien.

\section{DAFTAR PUSTAKA}

Abdul Kadir, 2003, Pengenalan Sistem Informasi, Andi, Yogyakarta.

Azhar Susanto, 2004. Sistem Informasi Manajemen.Bandung: Linggar Jaya.

Jogiyanto. 2013. Analisis \& Desain Sistem Informasi : Pendekatan tertruktur teori dan praktik aplikasi bisnis. Andi Offset. Yogyakarta

Kenneth C. Laudon, Jane P. Laudon, 2008. Sistem Informasi Manajemen, Edisi 10, Selamba Empat

Mursyidi 2010, Akuntansi Biaya Conventional Costing. Just In Time, dan Activity-Based Costing. Bandung: PT Refika Aditama

Peraturan Menteri Dalam Negeri Nomor 113 Tahun 2014 Tentang Pengelolaan Keuangan Desa

Peraturan Menteri Dalam Negeri Nomor 37 Tahun 2014 Tentang Pedoman Penyusunan APBD Tahun Anggaran 2015

O'Brien \& Marakas. (2009). Management Information Systems.Ninth Edition. New York: McGraw-Hill/Irwin

Rudianto, 2012, Pengantar Akuntansi Konsep \& Teknik Penyusunan Laporan Keuangan, Penerbit: Erlangga, Jakarta

Soemarso, S.R. 2009. Akuntansi Suatu Pengantar, Edisi kelima. Jakarta: Salemba Empat
Sjadzali, Munawir. 2004. Analisis Laporan Keuangan. Edisi Ke-4 Liberty. Yogyakarta.

Sugiyono, 2013, Metodelogi Penelitian Kuantitatif, Kualitatif Dan $R \& D$. (Bandung: ALFABETA)

Utomo, T. W., dan A. Wahyudi., 2008. Penataan kewenangan (urusan) pemerintah desa dan pengembangan standar pelayanan minimal (SPM). Jurnal Borneo Administrasi Vol. 4 No. 2

Warren, Reeve, Fess, Penerjemah Aria Farahmita, Amanugrahani dan Taufik Hendrawan. 2005. Accounting Pengantar Akuntansi Buku I Edisi 21. Jakarta: Salemba Empat.

Merystika Kabuhung, Sistem Informasi Akuntansi Penerimaan dan Pengeluaran Kas Untuk Perencanaan dan Pengedalian Keuangan Pada Organisasi Nirlaba Keagamaan, Jurnal EMBA: Jurnal Riset Ekonomi, Manajemen, Bisnis dan Akuntansi Vol 1 No 3 Tahun 2013, ISSN 23031174

Agatha Gema Mahardika, Udi Pramiudi, Arief FahmiPeranan, Penerapan Sistem Akuntansi Accurate Terhadap Penyusunan Laporan Keuangan (Studi Kasus Pada Umkm Toko Textile Leuwi Di Bogor), JIAKES Jurnal Ilmiah Akuntansi Kesatuan Vol. 7 No. 1 April Tahun 2019 pp. 193-196, ISSN 2337 -7852 